\title{
Physicochemical and Chromatographic Profiles of Distilled Sugarcane Spirits Produced in Mozambique
}

\author{
Manuel Carlos Minez Tábua1, Maria das Graças Cardoso ${ }^{*}$, Wilder Douglas Santiago1, \\ Gustavo da Silva Gonçalves', Richard Bispo Barbosa', Allan da Silva Lunguinho', \\ Renan Elan da Silva Oliveira², Gabriel Biscotto d'Avila², Maísa Lamounier Magalhães², \\ David Lee Nelson ${ }^{3}$ \\ ${ }^{1}$ Department of Chemistry, Federal University of Lavras, Lavras, MG, Brazil \\ ${ }^{2}$ Department of Food Science, Federal University of Lavras, Lavras, MG, Brazil \\ ${ }^{3}$ Pro-Reitoria de Pesquisa e Pós-Graduação, Federal University of Vales de Jequitinhonha and Mucuri, Diamantina, MG, Brazil \\ Email: ${ }^{\star}$ mcardoso@dqi.ufla.br
}

How to cite this paper: Tábua, M.C.M., Cardoso, M.G., Santiago, W.D., Gonçalves, G. da S., Barbosa, R.B., Lunguinho, A. da S., Oliveira, R.E. da S., d'Avila, G.B., Magalhães, M.L. and Nelson, D.L. (2018) Physicochemical and Chromatographic Profiles of Distilled Sugarcane Spirits Produced in Mozambique. American Journal of Plant Sciences, 9, 617-627. https://doi.org/10.4236/ajps.2018.94048

Received: January 17, 2018

Accepted: March 6, 2018

Published: March 9, 2018

Copyright (๑) 2018 by authors and Scientific Research Publishing Inc. This work is licensed under the Creative Commons Attribution International License (CC BY 4.0).

http://creativecommons.org/licenses/by/4.0/ c) (†) Open Access

\begin{abstract}
Knowledge of the chemical composition of Mozambican spirits is extremely important because the studies of potentially toxic compounds have been a determinant factor in quality control. The objectives of this work were to analyze and physicochemically characterize distilled sugarcane spirits and other raw materials from Mozambique on the basis of the standards established by the Brazilian Ministry of Agriculture, Livestock and Food Supply (MAPA). The samples came from five provinces of southern and central Mozambique, provided by the owners of the stills in the localities of Manhiça, Xinavane, Chókwe, Massinga, Mafambisse, Beira and Chimoio. The four samples from Brazil were randomly collected from different regions of Minas Gerais. The parameters analyzed were ethanol, methanol, higher alcohols, aldehydes, volatile acidity, furfural, esters and copper concentrations. The Mozambican spirits produced from different raw materials, compared to Brazilian spirits, contained very variable concentrations of the components analyzed. Mozambican spirits are of much lower quality than Brazilian beverages and are not suitable for consumption.
\end{abstract}

\section{Keywords}

Mozambican Liquor, Quality, Distilled Alcoholic Beverages

\section{Introduction}

Sugar cane spirits are produced in Mozambique by small producers in the 
Northern, Central and Southern regions. The scale of production is very precarious and without any registration of trademarks. The different forms of production and the types of raw material result in a variable qualities in terms of flavor and aroma, so the products receive different designations in said regions. Producers often use molasses and cereals such as corn, sorghum or rice as their raw materials.

Most of the production of spirits is of a family nature, employing rudimentary techniques. These families are dedicated to the production of sugarcane spirits, the head of the family is the individual who performs the activities of preparation and processing of the raw material, and the spouse is often responsible for the commercialization.

In some localities in the southern and central regions of Mozambique, spirits are produced for the sustenance of the families. Therefore, it is necessary for these producers to have a certain knowledge of new production technologies and the methods of transformation of the raw material available for producing quality spirits. The production of alcoholic beverages in Mozambique consists of the fermentation of several cereals or their simple or mixed brans, wild and cultivated fruits and sugarcane, using yeast or dried and ground germinated cereal as fermentative agents [1]. The objectives of this work were to analyze and characterize physicochemically sugarcane spirits and other raw materials from Mozambique on the basis of the standards established by the Brazilian Ministry of Agriculture, Livestock and Supply.

\section{Material and Methods}

\subsection{Sample Collection}

The samples were collected from five provinces of southern and central Mozambique, including the localities of Manhiça, Xinavane, Chókwe, Massinga, Mafambisse, Beira and Chimoio, and they were provided by the owners of the stills, in the period between August 2016 and May 2017. The District of Manhiça is located between the parallels $24^{\circ} 58^{\prime} 49^{\prime \prime}$ and $25^{\circ} 35^{\prime} 46^{\prime \prime}$ South latitude and between the meridians $32^{\circ} 30^{\prime} 51^{\prime \prime}$ and $33^{\circ} 08^{\prime} 14^{\prime \prime}$ East longitude. The town of Xinavane lies between the parallels $25^{\circ} 0^{\prime} 34^{\prime \prime}$ South and between $32^{\circ} 45^{\prime} 04^{\prime \prime}$ East. The district of Chókwe is georeferenced between parallels $24^{\circ} 05^{\prime}$ and $24^{\circ} 48^{\prime}$ South and $32^{\circ} 33^{\prime}$ and $33^{\circ} 35^{\prime}$ East. The Massinga district is located between the parallels $22^{\circ} 39^{\prime}$ and $23^{\circ} 31^{\prime}$ South and the meridians $34^{\circ} 54^{\prime}$ and $35^{\circ} 36^{\prime}$ East. The district of Mafambisse is located between the parallels $19^{\circ} 32^{\prime} 57^{\prime \prime}$ South and between $34^{\circ} 37^{\prime} 28^{\prime \prime}$ East. For the Beira district, it is georeferenced between the parallels $19^{\circ} 50^{\prime} 36^{\prime \prime}$ South and between $34^{\circ} 50^{\prime} 20^{\prime \prime}$ East. And the district of Chimoio is located between the parallels $19^{\circ} 06^{\prime} 59^{\prime \prime}$ South and between $33^{\circ} 28^{\prime} 59^{\prime \prime}$ East.

The four samples from Brazil were randomly collected from different regions of the state of Minas Gerais, Brazil. All the samples were identified by regions of origin and sent to the Laboratory of Analysis of Spirit Quality (LAQA), Depart- 
ment of Chemistry, Federal University of Lavras. The characteristics of the samples, as well as the region of origin, the alcohol concentration, and the raw material used in its production are presented in Table 1.

\subsection{Physicochemical Analysis}

The physicochemical analyses were performed at the Laboratory for the Analysis of Spirit Quality, Department of Chemistry, Federal University of Lavras according to the methods recommended by the Ministry of Agriculture, Livestock and Supply (MAPA) [2]. The samples were redistilled and stored in sealed glass bottles under refrigeration. All the analyses were performed in triplicate. The parameters analyzed by the respective analytical methods are described below:

The alcohol concentration was determined by densitometry, and the result was expressed in percent volume. The samples were redistilled, and the alcohol content was determined by measurements at $20^{\circ} \mathrm{C}$ with the aid of a digital hydrometer (DensiMat Gilbertini).

The volatile acidity was determined by volumetric titration. The volatile acids were extracted by steam distillation using a Gilbertini Electronic Enochimico Distiller. The acids obtained were titrated with $0.1 \mathrm{M} \mathrm{NaOH}$ in the presence of $1 \%$ phenolphthalein as an indicator. The results were expressed in grams of acetic acid per $100 \mathrm{~mL}$ of sample.

Table 1. Description of the samples by place of origin and raw material.

\begin{tabular}{|c|c|c|c|c|}
\hline Sample & Origin & $\begin{array}{c}\text { Raw } \\
\text { Material }\end{array}$ & Type of still & $\begin{array}{c}\text { Alcohol Concentration } \\
(\% \mathrm{v} / \mathrm{v})\end{array}$ \\
\hline 1 & Manhiça & Cane & Alambic & 40.49 \\
\hline 2 & Manhiça & Cane & Alambic & 47.38 \\
\hline 3 & Xinavane & Cane & Alambic & 41.58 \\
\hline 4 & Xinavane & Cane & Alambic & 40.08 \\
\hline 5 & Chokwe & Cashew & Alambic & 20.8 \\
\hline 6 & Chokwe & Cashew & Alambic & 20.96 \\
\hline 7 & Massinga & Nuts & Alambic & 56.1 \\
\hline 8 & Massinga & Nuts & Alambic & 55.8 \\
\hline 9 & Mafambisse & Cane & Alambic & 35.2 \\
\hline 10 & Mafambisse & Cane & Alambic & 37.06 \\
\hline 11 & Beira & Cereal & Alambic & 21.3 \\
\hline 12 & Chimoio & Cereal & Alambic & 58.1 \\
\hline 13 & Chimoio & Cereal & Alambic & 21.58 \\
\hline 14 & Minas Gerais & Cane & Alambic & 38.31 \\
\hline 15 & Minas Gerais & Cane & Alambic & 40.08 \\
\hline 16 & Minas Gerais & Cane & Alambic & 44.09 \\
\hline 17 & Minas Gerais & Cane & Alambic & 40.15 \\
\hline
\end{tabular}


Aldehydes were analyzed by direct titration of the $\mathrm{SO}_{2}$ formed by the reactions involved in the analysis with $0.05 \mathrm{M}$ iodine. The amount of aldehyde was expressed in grams of acetaldehyde per $100 \mathrm{~mL}$ of sample [2].

The determination of furfural was accomplished by means of spectrophotometric readings at $520 \mathrm{~nm}$ (Shimadzu UV-1601 PC) and by comparison of the absorbance observed in the beverage samples with those of a calibration curve previously constructed with standard solutions of ethanol and furfural. The alcoholic strength of the distillate was corrected to $50^{\circ} \mathrm{GL}$. The results were expressed as milligrams of furfural in $100 \mathrm{~mL}$ of anhydrous ethanol.

Esters were determined by titration of the carboxylic acid esters obtained by transesterification of the beverages. The concentrations were expressed in grams of ethyl acetate per $100 \mathrm{~mL}$ of ethanol.

Copper was determined by two procedures: 1) The Official MAP method. Copper analysis was performed by spectrophotometric (Shimadzu UV-1601 PC) measurements at $546 \mathrm{~nm}$ that were compared with the absorbance values of a calibration curve previously constructed using copper sulfate as the primary standard. The colorimetric reactions were performed on cachaças prior to redistilling. The results were expressed in $\mathrm{mg} / \mathrm{L}$ of anhydrous ethanol. 2) Analysis by atomic absorption. The concentrations of copper $(\mathrm{Cu})$ were determined by Flame Atomic Absorption Spectrometry, using the Varian Spectr AA 110 Atomic Absorption Spectrophotometer. The analytical curve was obtained using Merck standards at the following concentrations: $0.5 ; 1.0 ; 2.0 ; 4.0 ; 8.0 \mathrm{mg} \cdot \mathrm{L}^{-1}$. All the evaluations were performed at the wavelength of $324 \mathrm{~nm}$ for copper using a hollow cathode lamp. For the preparation of the samples, the method $\mathrm{N}^{\circ} 11$ of the Manual of Methods of Analysis of Beverages and Vinegars proposed by MAPA [2] was employed. The 50-mL aliquots were evaporated in a water bath at $85^{\circ} \mathrm{C}$ to a volume of $10 \mathrm{~mL}$. After evaporation, the sample was removed from the water bath and allowed to cool for a period of 2 hours until it reached room temperature. The sample was transfered to a $50-\mathrm{mL}$ volumetric flask, the volume was completed with distilled water, and the direct reading was performed in the atomic absorption apparatus. The results obtained were expressed in $\mathrm{mg} \cdot \mathrm{L}^{-1}$ and compared with the levels permitted by the Brazilian Legislation [3].

\subsection{Chromatographic Analyzes (GC-FID)}

\section{Determination of Higher Alcohols and Methanol}

A model GC 2010 gas chromatograph (GC) with automatic injection and a flame ionization detector (FID) was used in the Laboratory of the Analytical Center for Chemistry Prospecting (CAPQ) of the Department of Chemistry of the Federal University of Lavras. The column employed for analysis of the higher alcohols (propane-1-ol, butan-1-ol, butan-2-ol, and 3-methylbutan-1-ol) and methanol was the DB-Shimadzu polyethylene glycol $(30 \mathrm{~m} \times 0.25 \mathrm{~mm} \times 0.25 \mu \mathrm{m})$ column. The injection occurred at $150^{\circ} \mathrm{C}$ and detection at $170^{\circ} \mathrm{C}$. The injected volume was $1.0 \mu \mathrm{L}$. The split ratio was 1:10. The carrier gas was helium with a linear ve- 
locity of $1.4 \mathrm{~mL} \cdot \mathrm{min}^{-1}$. In this method, the analytical curves were constructed from previously known concentrations at certain concentration ranges by means of dilutions of the stock solution of each alcohol analyzed. The results were obtained from the regression equations and the correlation coefficients of the standard curve (Figure 1).

\section{Results and Discussion}

The mean values for the volatile acidity, aldehyde, copper and ester concentrations are listed in Table 2. The mean value for the volatile acid content of Mozambican spirits was $76 \%$, which presented a volatile acidity level greater than that permitted by MAPA (150 mg $100 \mathrm{~mL}^{-1}$ aa), with the exception of samples 7 , 8 and 12 , which presented values of $34.134,34.269$ and $94.532 \mathrm{mg} 100 \mathrm{~mL}^{-1}$ aa, respectively, and were within the limits established by Brazilian legislation [3]. The same is not true of the samples of Brazilian spirits, all of which were within the legal limits, ranging from 15.38 to $113.94 \mathrm{mg} 100 \mathrm{~mL}^{-1}$ aa. For Cardoso [4], the high acidity present in spirits/cachaças can be attributed to the contamination of the raw material or of the wine itself by acetic and other bacteria, resulting from an excessive rest period between the fermentation process and the distillation or a lack of hygiene throughout the production chain, especially during fermentation. Contamination causes the substrate to undergo acetic fermentation, which increases the acidity and diminishes the yield of ethanol.

Among the Mozambican spirits analyzed, 69.2\% were outside the limits permitted by MAPA for the aldehyde concentration. Only samples 2, 7, 8 and 12, with concentrations of 22.62,21.38; 21.87 and $14.59 \mathrm{mg} 100 \mathrm{~mL}^{-1}$ aa were within the limits established by MAPA ( $30 \mathrm{mg} 100 \mathrm{~mL}^{-1}$ ); the other spirits contained concentrations greater than that established by the Brazilian legislation. The aldehyde concentration ranged from 14.59 to $114.74 \mathrm{mg} 100 \mathrm{~mL}^{-1}$ aa. All the Brazilian spirits were within the legal limits, ranging from 10.12 to $17.37 \mathrm{mg} 100$ $\mathrm{mL}^{-1}$ aa.

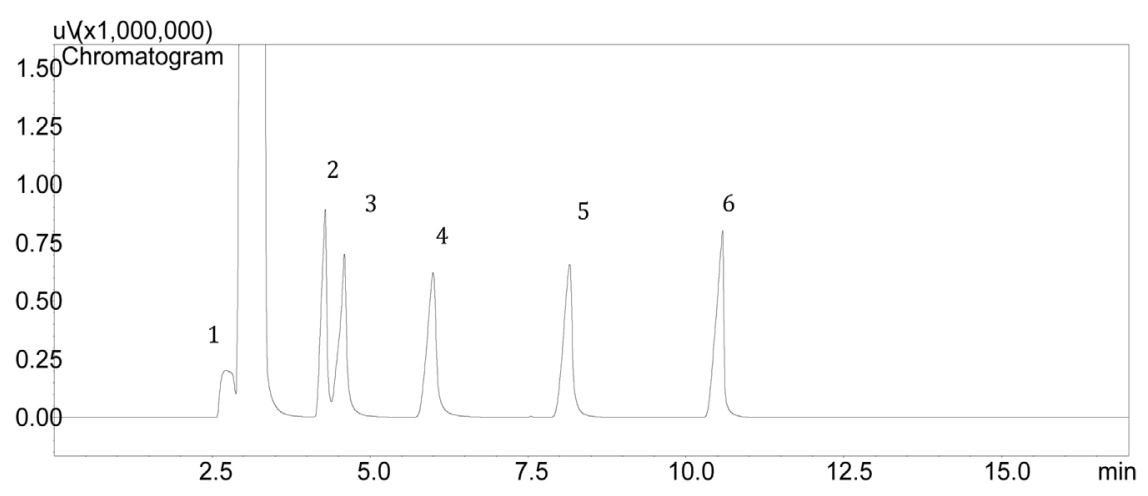

1_Metanol; 2_Butan-2-ol; 3_Propan-1-ol; 4_Álcool isobutílico; 5_Butan-1-ol; 6 _ Álcool isoamílico.

Figure 1. Chromatogram of higher alcohols and methanol. 
Table 2. Total volatile acidity, aldehydes, copper and ester concentrations of distilled spirits collected in Mozambique and Minas Gerais.

\begin{tabular}{|c|c|c|c|c|}
\hline Sample & $\begin{array}{l}\text { Volatile acidity } \\
\left(\mathrm{mg} 100 \mathrm{~mL}^{-1} \mathrm{aa}\right)\end{array}$ & $\begin{array}{c}\text { Aldehydes } \\
\left(\mathrm{mg} 100 \mathrm{~mL}^{-1} \mathrm{aa}\right)\end{array}$ & $\begin{array}{l}\text { Copper } \\
\left(\mathrm{mg} \cdot \mathrm{L}^{-1}\right)\end{array}$ & $\begin{array}{c}\text { Ésters } \\
\text { (mg } 100 \mathrm{~mL}^{-1} \text { aa) }\end{array}$ \\
\hline 1 & $465.560 c^{*}$ & $34.563 \mathrm{e}^{*}$ & ND & $63.741 \mathrm{c}$ \\
\hline 2 & $185.783 \mathrm{~h}^{*}$ & $22.622 \mathrm{~g}$ & ND & $35.428 \mathrm{~d}$ \\
\hline 3 & $267.458 \mathrm{~g}^{*}$ & $60.426 \mathrm{~d}^{*}$ & ND & $53.259 \mathrm{~d}$ \\
\hline 4 & $279.340 \mathrm{f}^{\star}$ & $32.195 \mathrm{f}$ & $1.550 \mathrm{e}$ & $82.892 \mathrm{c}$ \\
\hline 5 & $509.594 \mathrm{~b}^{*}$ & $114.749 \mathrm{a}^{*}$ & ND & $151.456 \mathrm{a}$ \\
\hline 6 & $520.087 \mathrm{a}^{*}$ & $114.487 \mathrm{a}^{*}$ & ND & $150.364 \mathrm{a}$ \\
\hline 7 & $34.134 \mathrm{n}$ & $21.385 \mathrm{~g}$ & ND & $39.476 \mathrm{~d}$ \\
\hline 8 & $34.269 \mathrm{n}$ & $21.874 \mathrm{~g}$ & ND & $36.583 \mathrm{~d}$ \\
\hline 9 & $162.968 \mathrm{i}^{*}$ & $32.852 \mathrm{f}^{*}$ & $7.617 \mathrm{a}^{*}$ & $36.258 \mathrm{~d}$ \\
\hline 10 & $182.868 \mathrm{~h}^{*}$ & $35.124 \mathrm{e}^{\star}$ & $5.981 \mathrm{~b}$ & $62.060 \mathrm{c}$ \\
\hline 11 & $387.290 \mathrm{e}^{*}$ & $102.026 \mathrm{~b}^{*}$ & ND & $119.972 \mathrm{~b}$ \\
\hline 12 & $94.532 \mathrm{k}$ & $14.598 \mathrm{i}$ & ND & $67.397 \mathrm{c}$ \\
\hline 13 & $392.432 \mathrm{~d}^{*}$ & $99.113 c^{*}$ & ND & $77.176 \mathrm{c}$ \\
\hline 14 & $15.381 \mathrm{o}$ & $12.114 \mathrm{j}$ & $0.213 \mathrm{~g}$ & $20.446 \mathrm{~d}$ \\
\hline 15 & $113.941 \mathrm{j}$ & $16.945 \mathrm{~h}$ & $0.725 \mathrm{f}$ & $86.858 \mathrm{c}$ \\
\hline 16 & $53.454 \mathrm{~m}$ & $17.371 \mathrm{~h}$ & $4.377 \mathrm{c}$ & $45.121 \mathrm{~d}$ \\
\hline 17 & 62.3671 & $10.128 \mathrm{k}$ & $2.257 \mathrm{~d}$ & $27.493 \mathrm{~d}$ \\
\hline
\end{tabular}

The means followed by the same letter in the columns do not differ from one another by the Scott Knott test at the $5 \%$ probability level. Results with an asterisk $\left(^{*}\right)$ are beyond the limits of the Standards for Identity and Quality [3].

Methanol and acetaldehyde are compounds that are characteristic of the head fraction because they are substances that are very volatile [4] [5]. For Serafim et al. [6], aldehydes are compounds responsible for the definition and consequent separation of the group of compounds referred to as the head fraction because this compound is very volatile.

Therefore, the moment of making the cuts of the fractions to avoid contamination of the heart fraction by an excess of organic contaminants that are harmful to human health is very important. According to Pereira [7], the distillation process is important for separating the volatile components (water, ethanol, methanol, higher alcohols, acetic acid, esters, aldehydes, carbon dioxide, etc.) from the fixed or non-volatile components, which are solids (yeast cells, minerals, organic and inorganic acids). The volatile compounds are distilled according to their boiling temperatures, alcohol/water affinity and alcohol content in the vapor phase, which favors the differentiation of the chemical composition of each fraction collected during the distillation of the beverage.

The mean concentrations of the esters were all within the limits required by Brazilian legislation $\left(200 \mathrm{mg} 100 \mathrm{~mL}^{-1}\right)$, with levels varying from 27.493 to $151.456 \mathrm{mg} 100 \mathrm{~mL}^{-1}$ aa. Among the Mozambican samples numbers 2, 3, 7, 8 and 9, no significant differences in their ester contents were observed when 
compared with Brazilian spirits 14, 16 and 17.

The formation of the esters occurs during distillation and in the aging process via a direct chemical reaction between acids and alcohols, but on a much smaller scale than the enzymatic pathway [8]. In samples of cachaça analyzed by Vilela et al. [9], no ester concentrations were observed to be beyond the established limits, but this result was to be expected because the samples were freshly distilled. The mean concentrations of higher alcohols, furfural, ethanol and methanol in the spirits analyzed are listed in Table 3.

Table 3. Mean concentrations of ethanol, methanol and higher alcohols in the spirits collected in Mozambique and Brazil.

\begin{tabular}{|c|c|c|c|c|}
\hline Sample & $\begin{array}{c}\text { Furfural } \\
\left(\mathrm{mg} 100 \mathrm{~mL}^{-1} \mathrm{aa}\right)\end{array}$ & $\begin{array}{l}\text { Ethanol } \\
(\% \mathrm{v} / \mathrm{v})\end{array}$ & $\begin{array}{c}\text { Metanol } \\
\left(\mathrm{mg} 100 \mathrm{~mL}^{-1} \mathrm{aa}\right)\end{array}$ & $\begin{array}{l}\text { Higher alcohols } \\
\left(\mathrm{mg} 100 \mathrm{~mL}^{-1} \text { aa) }\right.\end{array}$ \\
\hline 1 & $6.903 \mathrm{~h}^{\star}$ & $30.490 \mathrm{c}$ & $1.909 \mathrm{~d}$ & $212.799 \mathrm{~g}$ \\
\hline 2 & $3.531 \mathrm{i}$ & $47.380 \mathrm{~b}$ & $2.893 \mathrm{~d}$ & $245.080 \mathrm{e}$ \\
\hline 3 & $6.635 \mathrm{~h}^{*}$ & $41.585 \mathrm{~b}$ & $1.449 \mathrm{~d}$ & $265.538 \mathrm{~d}$ \\
\hline 4 & $10.246 \mathrm{~g}^{\star}$ & $40.080 \mathrm{~b}$ & $1.571 \mathrm{~d}$ & $225.425 \mathrm{f}$ \\
\hline 5 & $26.183 \mathrm{~b}^{*}$ & $20.815 \mathrm{~d}$ & $129.012 c^{*}$ & $166.481 \mathrm{i}$ \\
\hline 6 & $27.024 \mathrm{a}^{*}$ & $20.960 \mathrm{~d}$ & $131.224 c^{\star}$ & $169.255 \mathrm{i}$ \\
\hline 7 & $2.854 \mathrm{j}$ & $56.105 \mathrm{a}^{*}$ & $0.799 \mathrm{~d}$ & $206.734 \mathrm{~h}$ \\
\hline 8 & $14.336 \mathrm{f}^{*}$ & $55.885 \mathrm{a}^{*}$ & $0.784 \mathrm{~d}$ & $207.989 \mathrm{~h}$ \\
\hline 9 & $19.161 \mathrm{~d}^{*}$ & $35.265 \mathrm{~b}$ & $1.071 \mathrm{~d}$ & $307.013 \mathrm{~b}$ \\
\hline 10 & $16.035 \mathrm{e}^{\star}$ & $37.060 \mathrm{~b}$ & $0.665 \mathrm{~d}$ & $278.397 \mathrm{c}$ \\
\hline 11 & $25.754 b^{*}$ & $21.305 \mathrm{~d}$ & $173.296 b^{*}$ & $344.597 \mathrm{a}$ \\
\hline 12 & $6.366 \mathrm{~h}^{*}$ & $58.145 \mathrm{a}^{*}$ & $0.920 \mathrm{~d}$ & $202.806 \mathrm{~h}$ \\
\hline 13 & $23.420 c^{*}$ & $21.585 \mathrm{~d}$ & $191.855 \mathrm{a}^{\star}$ & $340.600 \mathrm{a}$ \\
\hline 14 & $0.287 \mathrm{k}$ & $38.310 \mathrm{~b}$ & $0.000 \mathrm{~d}$ & $154.850 \mathrm{j}$ \\
\hline 15 & $0.633 \mathrm{k}$ & $40.080 \mathrm{~b}$ & $0.000 \mathrm{~d}$ & $171.575 \mathrm{i}$ \\
\hline 16 & $0.640 \mathrm{k}$ & $44.095 \mathrm{~b}$ & $0.000 \mathrm{~d}$ & $155.059 \mathrm{j}$ \\
\hline 17 & $0.696 \mathrm{k}$ & $40.155 \mathrm{~b}$ & $0.000 \mathrm{~d}$ & $167.352 \mathrm{i}$ \\
\hline
\end{tabular}

The means followed by the same letter in the columns do not differ from one another by the Scott-Knott test a the $5 \%$ probability level. Results with an asterisk $\left({ }^{*}\right)$ are outside the limits of Identity and Quality [3].

The furfural concentrations in Mozambican spirits ranged from 2.85 to 27.02 $\mathrm{mg} 100 \mathrm{~mL}^{-1}$ aa. Only samples 2 and 7 (15.38\%) were within the legal limits, and the remaining samples $(84.6 \%)$ were outside the limits established by the MAPA, which is $5 \mathrm{mg} 100 \mathrm{~mL}^{-1}$ of anhydrous alcohol. All the Brazilian spirits analyzed in this study contained furfural concentrations within the legal limits, and no significant difference between the spirits was found.

Research conducted by Zacaroni et al. [10] on contaminants of Brazilian spirits showed that the concentrations obtained for furfural varied from 4.28 to $39.78 \mathrm{mg} 100 \mathrm{~mL}^{-1}$ aa, these values being higher than the limit established by the MAPA. Previously, Masson et al. [11] compared samples of alembic sugarcane 
spirits produced with burned and unburned sugar cane and found that the sugar cane spirits contained $8.80 \mathrm{mg} 100 \mathrm{~mL}^{-1}$ aa furfural, a value above the legal limit. The authors concluded that the burning of sugarcane straw caused a significant increase in the furfural contents of the samples analyzed. This increase might be related to the presence of residual sugars, polysaccharides from bagasse, weak fermentation and excessive heat in the distillation boiler. According to the author, contamination of the beverage by furfural occurs because it is formed by the degradation of pentoses during the fermentation, distillation and aging stages of the beverage.

The mean alcohol concentrations observed in the spirits studied ranged from $20.81 \%$ to $58.14 \%$ v/v. Samples 2, 3, 4, 14, 15, 16 and 17 contained concentrations within the legal limits (38.0\% to $54.0 \%$ ); but those of samples 7, 8, 12 were above the established limits (56.10\%, 55.88\% and $58.14 \% \mathrm{v} / \mathrm{v}$, respectively). The alcohol concentrations in the remaining samples were below the limits required by the legislation.

There were no significant differences among the samples $2,3,4,9,10,14,15$, 16 and 17. This fact demonstrated that a high correlation of the type of raw material used with the alcoholic grade existed. With regard to samples with low alcoholic strength, several factors might have exerted an influence, such as the raw material used, inadequate cuts, and incorrect fermentation, among other factors. According to Cantão et al. [12], one of the possible causes for an alcohol concentration below the permitted limit for spirits/cachaça is the use of a long delay before distillation of the wort. This procedure causes losses by evaporation of the alcohol. In addition, another important factor is the cut of the head, heart and tail fractions in the distillation step.

Bogusz Jr. et al. [13] reported that the reduction of the alcohol content can also result from the accentuated addition of water to the distillate during the standardization of the spirits to obtain a better yield of the product. Later, Damasceno et al. [14] investigated the alcohol content and volatile acidity in samples of artisanal cachaças from the state of Minas Gerais, Brazil, and found that four samples of cachaças analyzed had values below $38^{\circ} \mathrm{GL}$ and could not be classified as spirits. For Zacaroni et al. [10], storage conditions of the beverage, such as moisture, temperature and porosity of the barrel, or incorrect cutting during the distillation step might be related to the low alcohol content of said samples.

The mean methanol concentrations in the Mozambican spirits ranged from 0.66 to $191.85 \mathrm{mg} 100 \mathrm{~mL}^{-1}$ aa, of which nine samples (69.23\%) were within the required limits, and four $(30.77 \%)$ samples contained concentrations higher than that established by the MAPA (20 mg $100 \mathrm{~mL}^{-1}$ aa), with significant differences among them. The concentrations of methanol in the Brazilian samples were within the legal limits. The data corroborate those found by Zacaroni et al. [10], who studied different types of Brazilian spirits and detected no methanol. This observation implies that the wort was probably filtered before distillation.

Methanol is an undesirable alcohol in the beverage because of its high toxicity. It is formed by the degradation of pectin, a polysaccharide present in sugarcane, 
during the processing and fermentation [7]. In the body, methanol is oxidized to formic acid and, subsequently, to carbon dioxide, causing a serious acidosis (lowering the $\mathrm{pH}$ of the blood) and affecting the respiratory system, which can lead to coma and even death. Ingestion, even in small quantities, over long periods can lead to blindness and death [4] [15].

The mean values for the sum of the concentrations of the higher alcohols in the spirits studied ranged from 154.85 to $344.59 \mathrm{mg} 100 \mathrm{~mL}^{-1}$ aa, meaning that they were within the maximum limits $\left(360 \mathrm{mg} 100 \mathrm{~mL}^{-1}\right.$ aa) established by Brazilian legislation. The lowest concentrations were found in the Brazilian samples. The presence of higher alcohols in alcoholic beverages improves the taste and aroma, but an excess has an inverse effect, that is, it is related to malaise, such as headaches, nausea and muscle weakness.

Miranda et al. [16] and Santiago et al. [17] evaluated cachaças stored in wooden casks, submitted to treatment with radiation for a period of 390 days, and observed the influence of the aging process, in which a slight increase in the concentration of higher alcohols occurs as a function of the aging time. Their results disagree with those found in the present study. The amount of higher alcohols in spirits/cachaças is influenced by the composition of the medium, temperature, aeration level and the strain of yeast. The synthesis of higher alcohols is stimulated by oxygen, and it is directly related to the growth rate of the yeast [4] [18]. The formation of higher alcohols can also be influenced by the process and type of equipment used during distillation [4].

\section{Conclusion}

The Mozambican spirits produced with different raw materials contained very variable concentrations of the components analyzed when compared to one another and the Brazilian spirits. With regard to the limits required by Brazilian legislation for spirits/cachaças, most Mozambican samples contained concentrations greater than the maximum limits established for alcohol, volatile acidity, furfural, and metanol. These findings in Mozambican spirits suggest that improvements in their production must be made, which means that the producers' difficulties in controlling the production system to ensure the quality of the beverage for consumers must be overcome.

\section{Acknowledgements}

The authors express their gratitude to the Conselho Nacional de Desenvolvimento Científico e Tecnológico (CNPQ), the Fundação de Amparo à Pesquisa do Estado de Minas Gerais (FAPEMIG), and the Coordenação de Aperfeiçoamento de Pessoal de Nível Superior (CAPES) for financial support and scholarships granted.

\section{References}

[1] Casadei, E. (1987) Tradicional Mozambican Alcoholic Beverages and Some Toxio- 
logical Aspects? Intensive Course on Ecotoxicology and Chemical Safety. ECO.

[2] Brasil (2005a) Ministério da Agricultura, Pecuária e Abastecimento. Instrução normativa $\mathrm{n}^{\circ} 24$, of setember 08, 2005. Approves the Operational Manual for Beverages and Vinagers.

[3] Brasil (2005) Ministério da Agricultura, Pecuária e Abastecimento. Instrução Normativa $\mathrm{n}^{\circ} 13$, of June 29, 2005. Diário Oficial da União, Brasília.

[4] Cardoso, M.G. (2013) Produção de aguardente de cana. [Production of Distilled Sugarcane Spirits.] 3rd Edition, Lavras: Editora UFLA, 340 p.

[5] Alcarde, A.R., et al. (2010) Aspectos da composição química e aceitação sensorial da aguardente de cana-de-açúcar envelhecida em tonéis de diferentes madeiras. [Aspects of the Chemical Composition and Sensorial Acceptance of Distilled Sugarcane Spirits Aged in Casks of Different Types of Wood.] Ciência e Tecnologia de Alimentos, 30, 226-232. https://doi.org/10.1590/S0101-20612010000500035

[6] Serafim, F.A.T., et al. (2012) Comparação do perfil químico entre cachaças de um mesmo vinho destiladas em alambiques e em colunas. [Comparison of the Chemical Profile between Cachaças from the Same Wort Distilled in Alambics and through Columns.] Química Nova, São Carlos, 35, 1412-1416. https://doi.org/10.1590/S0100-40422012000700023

[7] Pereira, N.E., Cardoso, M.G., Azevedo, S.M., Morais, A.R., Fernandes, W. and Aguiar, P.M. (2003) Compostos secundários em cachaças produzidas no Estado de Minas Gerais. [Secondary Compounds in Cachaças Produced in the State of Minas Gerais.] Ciência e Agrotecnologia, 27, 1068-1075.

https://doi.org/10.1590/S1413-70542003000500014

[8] Nóbrega, I.C.C. (2003) Análise dos compostos voláteis da aguardente de cana por concentração dinâmica do Headspace e cromatografia gasosa-espectrometria de massas. [Analysis of the Volatile Compounds from Distilled Sugarcane Spirits by Dynamic Headspace Concentration and Gas Chromatography-Mass Spectrometry.] Ciência e Tecnologia de Alimentos, 23, 210-212. https://doi.org/10.1590/S0101-20612003000200019

[9] Vilela, F.J., et al. (2007) Determinação das composições físico-químicas das cachaças do Sul de Minas Gerais e de suas misturas. [Determination of the Physicochemical Compositions of the Cachaça from the South of Minas Gerais and Their Blends.] Ciência e Agrotecnologia, Lavras, 31, 1089-1094. https://doi.org/10.1590/S1413-70542007000400022

[10] Zacaroni, L.M., et al. (2011) Caracterização e quantificação de contaminantes em aguardentes de cana. [Characterization and Quantification of the Contaminants in Distilled Sugarcane Spirits.] Química Nova, São Paulo, 34, 320-324. https://doi.org/10.1590/S0100-40422011000200026

[11] Masson, J., et al. (2007) Parâmetros físico-químicos e cromatográficos em aguardentes de cana queimada e não queimada. [Physicochemical and Chromatographic Parameters for Distilled Spirits from Burned and Unburned Sugar Cane.] Ciência e Agrotecnologia, 31, 1805-1810. https://doi.org/10.1590/S1413-70542007000600030

[12] Cantão, et al. (2010) Avaliação e remoção de cobre em aguardentes de cana pela utilização dos aluminossilicatos: zeólita e bentonita. [Evaluation and Removal of Copper from Distilled Sugarcane Spirits through the Use of Aluminum Silicates: Zeolite and Bentonite.] Ciência e Agrotecnologia, 34, 1109-1115. https://doi.org/10.1590/S1413-70542010000500005

[13] Bogusz, J.R.S., Montano, M.A. and Garbin, R. (2005) Níveis de cobre em amostras de cachaça produzidas na região. [Levels of Copper in Samples of Cachaça Pro- 
duced in the Region.] Brasil Ciência Rural, 35, 1436-1440.

[14] Damasceno, et al. (2013) Teor alcoólico e acidez volátil em amostras de cachaça artesanal comercializadas no Vale do Jequitinhonha-MG. [Alcohol Content and Volatile Acidity in Samples of Alambic Cachaça Commercialized in the Jequitinhonha Valley, MG.] Revista Multitexto, 2, 56-60.

[15] Miranda, et al. (2006) Estudo do efeito da irradiação gamma $\left({ }^{60} \mathrm{Co}\right)$ na qualidade da cachaça e no tonel de envelhecimento. [Study of the Effect of Gamma-Radiation $\left(60^{\circ} \mathrm{C}\right)$ on the Quality of Cachaça and the Aging Cask.] Ciência e Tecnologia de Alimentos, 26. https://doi.org/10.1590/S0101-20612006000400010

[16] Maia, et al. (2006) Tecnologia da Cachaça de Alambique. [Technology of Alambic Cachaça.] Sindbebidas, Belo Horizonte, Sebrae/MG, 129.

[17] Rodrigues, L.M.A., et al. (2014) Aged Sugarcane Spirit: Quantitation of Phenolic Compounds, Antibacterial and Antioxidant Activity. American Journal of Plant Sciences, 5, 2935-3942. https://doi.org/10.4236/ajps.2014.520309

[18] Santiago, W.D., et al. (2014) Comparison and Quantification of the Development of Phenolic Compounds during the Aging of Cachaça in Oak (Quercus sp.) and Amburana (Amburana cearensis) Barrels. American Journal of Plant Sciences, 5, 3140-3150. https://doi.org/10.4236/ajps.2014.521330 